\title{
Ieuan Franklin
}

The papers in this special edition come from a conference held at the Science Museum in London in April 2014 to mark the 50 th anniversary of BBC2. The papers presented at the conference represented a range of perspectives: academic researchers and media historians in universities, colleagues from the Science Museum and programme-makers. We have included a selection of these papers in this special edition, each shining light on the development and early years of the channel.

The media ecology has developed so exponentially in the intervening period that in some ways it is hard to know how to assess the anniversary historically, but it is also important to think about how the values and ideals with which the channel was formed can provide inspiration in the present and future. Shortly after the conference, Melvyn Bragg gave a speech at a celebration of the life of Richard Hoggart at Goldsmiths University (Hoggart died in April 2014), in which he suggested that the best tribute to the man who had been so instrumental in the formulation of the Pilkington Report of 1960 (and therefore the creation of BBC2) would be to attempt to find a way to revive the report (Bragg 2015). This led to an inquiry into the future of public service television, chaired by Goldsmiths, which published a wide-ranging report on the subject in $2016 .^{1}$

As is well documented, the national press vilified the report's critique of commercial broadcasting as elitist, puritan and 'killjoy', traducing Hoggart's clear commitment to democratic principles in broadcasting, and his hostility to both cultural elitism and the arrogance of 'free-marketeers' with the presumption to always know and state exactly what the television audience wanted. ${ }^{2}$ As is noted in the aforementioned Goldsmiths report, this 
traduction has been incredibly useful to the enemies of public service broadcasting, ${ }^{3}$ underlining the importance of revisiting and reappraising Pilkington and the ideas of the New Left about the role of broadcasting in society, which had a significant impact on the Report.

In considering the influence it had on the birth and early shape of the Corporation's second channel, it is worth acknowledging that the New Left's dynamism in the 1960s can be said to be have been partly derived from its connections with transformations in the arts more widely, where non-deferential and non-condescending realism was being combined with broadly modernist aesthetic approaches in film, TV drama, theatre, the novel and journalism (During 2009, p.99). Free Cinema, the Radio Ballads, the British New Wave, Arnold Wesker's Centre 42, and Joan Littlewood's Theatre Workshop are just some examples of this cultural stream in the late 1950 s and early 1960 s.

It is widely recognized that Richard Hoggart had a pivotal role in ensuring that the Corporation should be allotted the third channel and that television should give more attention to broadcasting for minorities, through his influence as a key member of the Pilkington Committee. Again and again the phraseology and arguments advanced by the report reflect his critical intelligence, which in retrospect was logical given Hoggart's literary experience and professional qualifications. The Report's characterization of television's triviality ('sins of commission') are sometimes reminiscent of his classic The Uses of Literacy (1957); 'Plays or serials might not deal with real human problems, but present a candy-floss world' (Report of the Committee on Broadcasting, p. 34). Hoggart envisioned instead television that would be 'imaginatively adventurous' (ibid.) What is rather less well known is that the influence of the New Left was reinforced by an impressive submission from New Left Review. This submission analysed in detail the most common genres in television and paid particular attention to the coming of a third channel. To quote from the document: 
The present structure is dominated either by the "commercial" voice of advertising or the "official" voice of a public institution. What is needed is other voices, faces, other interests, other interpretations of "entertainment", other approaches to "seriousness", other aspects of our community life...A Third Channel has the opportunity to do what neither the ITA nor BBC has been able to do; create a genuinely "popular" channel and trust the people who produce the programmes. (quoted in Hogenkamp 2000, p.68)

In its language and ideals this intervention in cultural policy can also be regarded as a precursor of the later campaign for a fourth channel. The arrival of BBC-2 was synonymous with an expansion in programming and personnel, boosted by younger, university-educated recruits. Between 1960 and 1968 the numbers employed by the BBC rose by 40\% (Darlow 2004, p.24). According to filmmaker and author Michael Darlow, once inside the BBC, 'they had started to live what one of them has called 'a protected lifestyle', in which there was time and an enthusiasm for a 'continuous debate' about the nature and purpose of broadcasting' (ibid., p. 23). Darlow further asserts that many of those who had joined the BBC in the early 1960s were influenced by the thinking of Raymond Williams and his ideas about culture, which were encapsulated in Culture and Society 1780-1950 (1958):

Williams argued that, in contrast to much of Europe, the BBC itself had only come into existence as a non-commercial public service institution independent of detailed state supervision as a consequence of Britain having had an unusually compact and cohesive ruling class, and a clear idea of both the national culture and of the national interest. However, by the early 1960s that ruling class was under challenge and the cultural consensus was breaking down. (ibid.)

Writing in The Listener days before the launch of BBC2, Stuart Hood acknowledged that the idea of culture or art as [being] 'the treasured privilege of the minority' was outmoded, and 
would not be the attitude taken by the new channel (Hood 1964). Chiming with the way in which the Pilkington Report had, in some respects, gone beyond mere consideration of television to appraise British culture in general (see Petley 2015), he stated that the question of why there is a need for a second channel 'is, in fact, a stalking-horse for more fundamental queries about the role of television in society' (Hood 1964, p.611). Hood goes on to outline the role of BBC-2 in a way which partly prefigures Channel 4's remit decades later; 'to increase the variety of programmes available to the viewer; to escape from the tyranny of the tight hour and half-hour schedule; and to experiment' (ibid., 612).

Initially BBC executives seemed to reject the principle of complimentarity as a way of achieving this escape from tyranny as too 'automatic and uncreative [a] procedure' (ibid.), fearing that the channel would be relegated to being a 'serious' shadow of $\mathrm{BBCl}$ 's relative populism. Instead the solution hit upon by BBC2's first Controller, Michael Peacock, was to assign each evening's programming a particular theme - so Monday was entertainment, Tuesday education, Wednesday repeats, and so on. Yet, in the days before video recording, 'there was not much point in alternative programming if programmes did not at least start or finish at the same time on the two networks' (Drummond 2000, p.139). This restrictive scheduling strategy received a great deal of criticism, and was quickly abandoned, which was a lesson learnt by Jeremy Isaacs, Channel 4's first Chief Executive when establishing the fourth channel:

It structured the programme in the first few months in a very off-putting way with whole evenings devoted to particular subjects. All that's very, very different now with stuff deliberately in the schedule that's popular so that people who come across to watch will watch other things too. (quoted in McKay 1982) 
Isaacs goes on to comment that 'the main thing about BBC2 I want to avoid if I positively can...is simply that it had then, and to some extent still has, a toffee-nosed, high-culture character which meant that an awful lot of British television viewers felt it was not for them' (ibid.). Hood had accepted that there would be 'more selectivity' (1964: 612) in the viewing of BBC-2, but in the early years there was perhaps not sufficient consideration of how the channel would develop and sustain an audience, albeit a 'minority audience'. The 'straitjacket of bizarre scheduling' (Drummond 2000, p.139), compounded with the fact that the channel could initially only be received in London and parts of the south-east of England, meant that BBC2 gave the unfortunate impression of pitching itself to an 'elite audience'. This was certainly not the intended approach, and it led to some commentators in the press caricaturing the television audience as divided between those 'in the pit' hooting and booing the idea of a minority service featuring 'Education Night' on a Tuesday, and the 'eggheads in the stalls and circle' later decrying the decision to replace this weekly educational programming with vintage Hollywood movies. ${ }^{4}$

The ten year plan for television submitted to Pilkington had, in fact, advocated precisely the kind of light/serious complimentarity that Hood and Peacock would initially reject as 'uncreative' - a relationship between two BBC channels that would set 'thought and opinion [...] against light entertainment, music against speech, serious drama against light comedy' (Briggs 1995: 286). In any case, as this special issue will demonstrate, what BBC2 did broadcast during its first ten years was far more creative than anything envisioned in either the ten year plan or Peacock's 'seven faces of the week' model of programming everything from groundbreaking long-form documentary series' like The Great War (1964) and Civilisation (1969); films from around the world (World Cinema, 1965-74); experimental dramas (such as those produced by John McGrath in 1964-6); and monthly programmes on 
science (Horizon, 1964 -), social science (The Human Side, 1964-5), literature (Writers' World, 1964-5) and music (Workshop, 1964-9).

\section{Notes}

1 'A Future for Public Service Television: Content and Platforms in a Digital World', Goldsmiths University of London, 2016, www.futureoftv.org.uk (accessed $6^{\text {st }}$ March 2017).

${ }^{2}$ For more on Hoggart's views about television, see Sue Owen, 'Richard Hoggart and the Uses of Television', Journal of British Cinema and Television, Volume 8, Issue 2, 2011, pp. 188-203.

${ }^{3}$ Professor Julian Petley, quoted in 'A Future for Public Service Television', p. 10.

${ }^{4}$ See Franklin's article in this issue.

\section{References}

Bragg, M., 2015. Richard Hoggart shows us to improve TV's future we must look to the past. The Guardian. Available at: https://www.theguardian.com/media/2015/nov/18/richard-hoggart-shows-us-toimprove-tvs-future-we-must-look-to-the-past [Accessed March 7, 2017].

Briggs, A. (1995), Competition: The History of Broadcasting in the United Kingdom Vol V. Oxford: Oxford University Press.

Darlow, M., 2004. Independents struggle : the programme makers who took on the TV establishment, London: Quartet,

Drummond, J., 2000. Tainted by Experience: A Life in the Arts, Faber.

During, S., 2009. Exit Capitalism: Literary Culture, Theory and Post-Secular Modernity, Routledge.

Hogenkamp, B., 2000. Film, Television and the Left in Britain, 1950 to 1970, Lawrence \& Wishart.

Hoggart, R., 1957. The Uses of Literacy, Transaction Publishers.

Hood, S., 1964. The BBC's Second Channel. The Listener, 71(1829), pp.611-612.

McKay, R., 1982. Who's This Channel Four? City Limits.

Petley, J., 2015. Richard Hoggart and Pilkington: Populism and public service broadcasting. Ethical Space, 12(1), pp.4-14.

Williams, R., 1958. Culture and society, 1780-1950, Columbia University Press. 